\title{
SURVEY OF KNOWLEDGE AND ATTITUDES OF HEAD NURSES REGARDING ORGAN TRANSPLANTATION
}

\author{
Željko Vlaisavljević1,2, Slobodan Janković2, Ivan Soldatović3
}

\begin{abstract}
Organ transplantation is the only therapeutic option for some diseases. The knowledge and attitudes of nurses regarding organ transplantation are vital for their proactive role in recruiting potential donors. Several factors may have a positive or negative influence on their attitudes, the most relevant of which are their religion, level of education and duration of employment. The aim of this study was to ascertain the level of knowledge and attitudes of head nurses regarding organ donation and transplantation, and to identify the factors with positive or negative impact. The majority of head nurses do not have sufficient knowledge about the Serbian Transplantation Law (77.8\%). Another major factor which influenced attitudes of head nurses regarding organ donation was their religion $(70.4 \%)$, and only $14.8 \%$ of head nurses agreed to be registered as potential organ donors.
\end{abstract}

Acta Medica Medianae 2017;56(4):38-44. technique, nurses

\author{
${ }^{1}$ Clinical Centre of Serbia, Clinic for Gastroenterolgy, Belgrade, \\ Serbia \\ ${ }^{2}$ University of Kragujevac, Faculty of Medical Science, \\ Kragujevac, Serbia \\ ${ }^{3}$ University of Belgrade, School of Medicine, Belgrade, Serbia \\ Contact: Željko Vlaisavljević \\ St. Dr Koste Todorovica 2, 11000 Belgrade, \\ E-mail: kcszeljko@gmail.com
}

Allport defines the term "attitude" as follows: "The attitude is a permanent mental, i.e. neural, readiness acquired on the basis of experience which directly or dynamically influences the reac-tion of an individual to objects and situations with which they are in touch" (2). This definition can be interpreted as a claim that attitudes exist as predispositions and are formed on the basis of experience through emotional (affective), cognitive and behavioral influences of the emotional (affective) and the cognitive. Crucial for the attitude formation are numerous factors which can be general universal, general direct and specific. General universal factors reflect the overall social environment and global historical perspective. Thus, it can be said that the overall environment (upbringing, religion, education, media etc.) influences the attitude formation. A research conducted in China suggests that an increase in knowledge through educational system, better training of medical staff and introducing subsidies would allow for a larger, more efficient organ donor system (3).

The goal of the survey was to evaluate the attitudes and knowledge of head nurses about organ bequest and transplantation. The survey required that the literature should be consulted, consensus reached, data from the key studies extracted, the results interpreted and the knowledge about the attitudes of the nurses on organ bequest and transplantation synthesized.

\section{Methodology}

The Delphi technique is a procedure which includes the experts via a panel discussion during 
which the questionnaires are distributed and the feedback is used for the purpose of reaching the group consensus on a certain topic. As an intuitive qualitative method, the Delphi technique provides the opportunity for acquiring the expert group opinion (4). This technique gives us the ability to perform the evaluation of the social needs, especially the attitudes, knowledge and level of information on particular topics. The Delphi technique has been rarely used for determination of the mutual attitude on organ bequest and transplantation. During the production of this survey we have used the COREQ Guide (Consolidated Criteria for Reporting Qualitative Research Guide) which was modified according to the purpose of the work.

Time and location of the survey:

The participants in this part of the survey were the head nurses of all hospitals in Serbia and the communication was made via e-mail. The members of the panel were selected based on their experience level and their job positions as head nurses/technicians of the wards and clinics. Using this technique, 27 head nurses of the hospital wards and clinics from different Serbian cities willing to answer the questions were surveyed: Clinical Center of Serbia (KCS), Hematology Clinic, Clinic of Allergology and Immunology of the Clinical Center of Serbia, Clinic of Gynecology and Obstetrics of the Clinical Center of Serbia, Clinic for Chest Surgery of the Clinical Center of Serbia, Clinic of Otorhinolaryngology and Maxillofacial Surgery of the Clinical Center of Serbia, Orthopedic Clinic of the Clinical Hospital Center "Zvezdara", Intensive Care Unit of the Health Center Kruševac, Surgery Ward of the General Hospital "Stefan Visoki" from Smederevska Palanka, University Children's Hospital "Tirsova", Clinic for Infective Diseases of the Clinical Center Niš, Surgical Intensive Care of the Clinical center of Kragujevac, Institute for Health Care of Mother and Children "Vukan Cupic, M.D.", Health Center of Air Serbia, Health Center of Novi Beograd, Health Center of Rakovica, Health Center of Šabac, Health Center of Subotica, Health Center of Kursumlija, Abdominal Surgery Clinic of the Clinical Center of Novi Sad, Intensive Care Unit of the Clinical Center of Novi Sad, Clinic for Neurosurgery of the Clinical Center of Novi Sad, Clinic for Aesthetic Surgery of the Clinical Center of Novi Sad, Clinic of Nephrology of the Clinical Center of Novi Sad, Clinic of Nephrology of the Clinical Center of Novi Sad Hemodialysis Ward, Orthopedic Clinic of the Clinical Center of Novi Sad, Emergency Surgery Ward of the Emergency Center of Novi Sad, Clinic for Immunology of the Clinical Center of Novi Sad, Clinic of Endocrinology of the Clinical Center of Novi Sad, Clinic of Gastroenterology and Hepatology of the Clinical Center of Novi Sad and Clinic of Hematology of the Clinical Center of Novi Sad. The survey was conducted in the period bet-ween September $24^{\text {th }}$ and December $13^{\text {th }}, 2014$.

\section{Data Collection and analysis:}

In order to reach the consensus, a threepart questionnaire was used. The first part focused on socio-demographic data; the second included the questions for evaluation of knowledge and information, while the third part of the questionnaire was based on attitude formation. All the questions about attitudes were connected and every question was made on the basis of the previous one. The survey of the attitudes about organ bequest and transplantation was conducted through a series of questions with the topics of organ bequest promotion, everyday jobs of the participants, desire to acquire and implement new knowledge and skills and the ethics of trans-plantology. All the subjects were informed about the purpose of the survey as well as about the fact that their answers will be analyzed and used for scientific purposes to produce a dissertation and scientific publications. The subjects participated anonymously, i.e. only the surveyors knew their identity. They answered the questions in several questi-

Table 1. Socio-demographic

\begin{tabular}{|c|c|}
\hline Socio-demographics & Total $(n=27)$ \\
\hline \multicolumn{2}{|l|}{ Gender } \\
\hline Male sex & 0 \\
\hline Female sex & 27 \\
\hline \multicolumn{2}{|l|}{ Education } \\
\hline $\begin{array}{c}\text { Secondary Medical } \\
\text { School }\end{array}$ & $5(18.5 \%)$ \\
\hline High school of medicine & $14(51.9 \%)$ \\
\hline Faculty of nurses & $8(29.6 \%)$ \\
\hline \multicolumn{2}{|l|}{ Living in } \\
\hline City & $24(88.9 \%)$ \\
\hline Small town & $1(3.7 \%)$ \\
\hline Village & $2(7.4)$ \\
\hline \multicolumn{2}{|l|}{ Marital Status } \\
\hline Free & $5(18.5 \%)$ \\
\hline Engaged & $4(14.8 \%)$ \\
\hline Married & $17(63.0 \%)$ \\
\hline Divorced & 0 \\
\hline Widow / widower & $1(3.7)$ \\
\hline \multicolumn{2}{|l|}{ Religion } \\
\hline Orthodox & $26(96.3 \%)$ \\
\hline Catholic & 0 \\
\hline Islam & $1(3.7 \%)$ \\
\hline \multicolumn{2}{|l|}{$\begin{array}{l}\text { Length of work } \\
\text { experience }\end{array}$} \\
\hline $\begin{array}{l}\text { The average length of } \\
\text { service }\end{array}$ & 23,037 \\
\hline \multicolumn{2}{|l|}{ Are you a blood donor? } \\
\hline Yes & $6(22.2 \%)$ \\
\hline No & $13(48.1 \%)$ \\
\hline Sometimes & $6(22.2 \%)$ \\
\hline $\begin{array}{c}\text { If you need someone in } \\
\text { the family }\end{array}$ & $2(7.4 \%)$ \\
\hline \multicolumn{2}{|l|}{$\begin{array}{c}\text { Familiar with } \\
\text { transplantation law? }\end{array}$} \\
\hline Yes & $6(22.2 \%)$ \\
\hline No & $21(77.8 \%)$ \\
\hline
\end{tabular}


oning rounds and each round was improved based on the feedback from the previous versions. There were threee rounds of answers for each question asked, after which a consensus was reached. The time to answer the questions was 10 to $15 \mathrm{mi}$ nutes. The rounds continued until a consensus was reached. The consensus was defined as at least $70 \%$ of identical positive or negative answers on all points of the same level i.e. the question group. This is in accordance with the recommended quality indicators for Delphi studies $(5,6)$. The first part of the survey dealt with the following data: gender, education level, duration of work experience, marital status, religion, place of residence, whether they were voluntary blood donors or not, as well as if they had the donor card. In the second part, the participants filled in a test of knowledge which is a part of the survey questionnaire and were evaluated with 1 and 2, depending on the answers they provided on transplantation and organ bequest, where 1 was used for correct answers and 2 for incorrect answers. The third part of the survey examined the attitudes on transplantation. Socio-demographic characteristics of the subjects are given in Table 1. All the participants answered all the questions. The processing of the data was done using the SPSS software package, version 18 .

\section{Results}

The main criterion to determine the experts i.e. the participants in the study was that the participant was the head nurse of a ward or an institution. This survey included 26 head nurses and 1 head medical technician, the majority of which had higher vocational or high vocational medical education $-14(51.9 \%)$, while only 8 $(29.6 \%)$ had faculty education and the function of the head nurse with secondary medical education was performed by 5 participants $(18.59 \%)$. The majority of the participants lived in the cities - 24 (88.9\%). Seventeen (17) participants (63\%) were married, while a lower number of participants were without a partner - 5 participants $(18.5 \%)$, and $4(14.8 \%)$ were engaged. There were no widows and widowers. The majority of participants in the panel were Orthodox Christians - 26 (96.3 $\%)$. The average duration of the work experience of the participants was 23 years. From the total of 27 participants, $13(48.1 \%)$ were not voluntary blood donors, while the numbers of participants who were blood donors - $6(22.2 \%)$ and occasional blood donors - $6(22.2 \%)$ were equal. The smallest number of participants stated that they would give blood only for their close relatives - 2 $(7.4 \%)$. The majority of participants were not acquainted with the Law on Transplantation - 21 $(77.8 \%)$

Knowledge of the participants was evaluated via a pre-validated questionnaire. Table 2 shows the results of the knowledge test, where the participants demonstrated a high level of knowledge and mainly gave correct answers to questions 13-
18 (the numbers of the correctly answered questions: $1,5,6,7,8,9,10,12,13,14,15,17,19)$. However, there was a small number of participants who answered the same questions incorrectly. After the test of knowledge, the third part of the survey was started with a series of questions about attitudes in connection to organ bequest and transplantation.

The consensus was reached about the importance of the nurses' role in the promotion of organ bequest and transplantation ( $81.5 \%)$ and that mass media also played an important role in the promotion $(92.6 \%)$. In addition, the participants believed that the Church had an important role in organ bequest promotion $(66.7 \%)$, and that the religion influenced the decision on organ bequest $(70.4 \%)$. The promotion of organ bequest between medical professionals only was not considered of great importance $(85.2 \%)$. The consensus was not reached about the question if studying transplantology in schools would help better response to organ bequest.

The third part of the survey was related to the attitudes about the questions based on everyday nursing practice. The participants of the panel agreed that the care for a brain-dead patient represented a psychological stress for them (92.6 $\%)$, but they also agreed that conducting it was not a problem $(85.2 \%)$. The consensus was also reached about the question if they would be capable of pointing in the right direction the grieving family ready to give consent for organ donation (85.2\%). Concerning the information about patient care, as well as about patient care at home, the consensus was not reached, since the participants believed that they did not have enough knowledge and information about giving adequate care to a patient who had transplantation and therefore they followed the instructions of the doctors $(37 \%)$, although they believed that it would be of great significance if a nurse could inform the patients about postoperative care and patient behavior $(66.7 \%)$. The participants of the panel reached the consensus about their wish to be better informed about the issue of organ bequest, as well as about organ transplantation ( $81.5 \%)$. They also agreed that they would like to improve their knowledge on the subject.

In the part of the survey dedicated to ethical issues, the participants of the panel agreed that it was ethical to ask the parents of a retarded person to give consent for organ donation $(70.4 \%)$, but they also thought that it was of great importance to give support to the donor's family (77.9 $\%)$. To set an example by bequesting one's own organs was the opinion of $66.7 \%$. However, only $14.8 \%$ of all participants had the donor card. Of the total number of panel participants $(N=27)$, about half had not talked to their families about organ bequests $(48.1 \%)$, but if they needed the transplantation, they would accept it $(96.3 \%)$. The participants $(63.0 \%)$ thought that all the people who bequeathed their organs, unlike the ones who did not, should have medical care and transplan- 
Table 2. The Knowledge of nurses abaut organ transplantation and bequest

\begin{tabular}{|c|c|c|c|}
\hline Question & $\mathrm{N}$ & Answers & $(\%)$ \\
\hline \multirow{2}{*}{$\begin{array}{l}\text { 1. Does an injury to the brain stem } \\
\text { lead to brain death: }\end{array}$} & \multirow{2}{*}{27} & Correct & $22(81.5 \%)$ \\
\hline & & Incorrect & $5(18.5 \%)$ \\
\hline \multirow{2}{*}{$\begin{array}{l}\text { 2. EEG is the most valid method for } \\
\text { determination of brain death? }\end{array}$} & \multirow{2}{*}{27} & Correct & $17(63.0 \%)$ \\
\hline & & Incorrect & $10(37.0 \%)$ \\
\hline \multirow{2}{*}{$\begin{array}{l}\text { 3.Stem cells are not used in organ } \\
\text { transplantation: }\end{array}$} & \multirow{2}{*}{27} & Correct & $10(37.0 \%)$ \\
\hline & & Incorrect & $17(63.0 \%)$ \\
\hline \multirow{2}{*}{$\begin{array}{c}\text { 4. Can patients with heart disease, } \\
\text { diabetes and obese people be organ } \\
\text { donors? }\end{array}$} & \multirow{2}{*}{27} & Correct & $12(44.4 \%)$ \\
\hline & & Incorrect & $15(55.6)$ \\
\hline \multirow{2}{*}{$\begin{array}{l}\text { 5.Until working heart and lungs brain } \\
\text { is alive: }\end{array}$} & \multirow{2}{*}{27} & Correct & $2(7.4 \%)$ \\
\hline & & Incorrect & $25(92.6 \%)$ \\
\hline \multirow{2}{*}{$\begin{array}{c}\text { 6. The organs should not be taken until } \\
\text { the heart and lungs failure? }\end{array}$} & \multirow{2}{*}{27} & Тачно & $4(14.8 \%)$ \\
\hline & & Incorrect & $23(85.2 \%)$ \\
\hline \multirow{2}{*}{$\begin{array}{l}\text { 7.In patients where brain death has } \\
\text { been determined and the heart and } \\
\text { lungs work there is a possibility that } \\
\text { the patient recovers: }\end{array}$} & \multirow[b]{2}{*}{27} & Correct & 0 \\
\hline & & Incorrect & $27(100 \%)$ \\
\hline \multirow{2}{*}{$\begin{array}{c}\text { 8. Every patient can get anyone's } \\
\text { organ? }\end{array}$} & \multirow{2}{*}{27} & Correct & $1(3.7 \%)$ \\
\hline & & Incorrect & $26(96.3 \%)$ \\
\hline \multirow{2}{*}{$\begin{array}{l}\text { 9. There are no adverse effects after } \\
\text { transplantation? }\end{array}$} & \multirow{2}{*}{27} & Correct & 0 \\
\hline & & Incorrect & $27(100 \%)$ \\
\hline \multirow{2}{*}{$\begin{array}{c}\text { 10.Donor must be dead to donate } \\
\text { organ: }\end{array}$} & \multirow{2}{*}{27} & Correct & $5(18.5 \%)$ \\
\hline & & Incorrect & $22(81.5 \%)$ \\
\hline \multirow{2}{*}{$\begin{array}{l}\text { 11.Children under } 16 \text { years cannot } \\
\text { give their organs without parental } \\
\text { consent? }\end{array}$} & \multirow[b]{2}{*}{27} & Correct & $14(51.9 \%)$ \\
\hline & & Incorrect & $13(48.1 \%)$ \\
\hline \multirow{2}{*}{$\begin{array}{c}\text { 12. One person can receive more } \\
\text { organs: }\end{array}$} & \multirow{2}{*}{27} & Correct & $18(66.7 \%)$ \\
\hline & & Incorrect & $9(33.3 \%)$ \\
\hline \multirow{2}{*}{$\begin{array}{l}\text { 13.Pancreas, small intestine and heart } \\
\text { can not be transplanted? }\end{array}$} & \multirow{2}{*}{27} & Correct & $1(3.7 \%)$ \\
\hline & & Incorrect & $26(96.3 \%)$ \\
\hline \multirow{2}{*}{$\begin{array}{l}\text { 14. One organ donor can help just one } \\
\text { ill: }\end{array}$} & \multirow{2}{*}{27} & Correct & $2(7.4 \%)$ \\
\hline & & Incorrect & $25(92.6 \%)$ \\
\hline \multirow{2}{*}{$\begin{array}{l}\text { 15. When taking organs from a patient } \\
\text { who was on life support and brain } \\
\text { dead, the patient does not feel pain: }\end{array}$} & רת & Correct & $22(81.5 \%)$ \\
\hline & 27 & Incorrect & $5(18.5 \%)$ \\
\hline 16. When a patient needs an organ, & 27 & Correct & $4(14.8 \%)$ \\
\hline he/she can buy it? & 21 & Incorrect & $23(85.2 \%)$ \\
\hline 17.Patients who are transplanted do & 27 & Correct & 0 \\
\hline not live longer than 5 years: & 21 & Incorrect & $27(100 \%)$ \\
\hline 18.Can Roma population bequest the & 27 & Yes & $23(85.2 \%)$ \\
\hline organs? & 21 & No & $4(14.8 \%)$ \\
\hline
\end{tabular}

tation benefits such as: better health insurance, shorter waiting time for examinations and diagnosis and priority on the transplantation waiting lists.

All the participants of the survey completed all the parts of the questionnaire which added to the validity of the survey. Through the first part of the questionnaire we acquired socio-demographic data; in the second part we got the estimate of knowledge and information on organ bequest and transplantation, while the third part of the questionnaire did not offer many new ideas and comments to further develop the survey of attitudes through a consequent series of questions. Some of the statements were very confusing and poorly defined and for this reason it was not possible to give feedback about them or to further process them.

\section{Discussion}

There are numerous definitions of transplantation. The Law on Transplantation of the Republic of Serbia defines the term "transplantation" as follows: "Transplantation is a medical procedure of taking organs, i.e. cells or tissue, from a living or deceased person for the purpose of transplanting it into the body of another person under medical treatment, including the preparation, processing, preservation, monitoring of serious side effects, as well as the distribution of an organ or its parts." (7). The essence of the transplantation process is 
to heal the person in need of an organ. The surgical procedure demands a multi-disciplinary approach, but the same goes for organ acquisition. Nurses are in close contact with the patients and their relatives and therefore it can be said that they are of crucial significance for the process of organ donation as intermediaries between the patient and the family of a potential donor. If the emphasis is put on understanding the nature of the transplantation process by potential donors, then we can say that the empathic attitude established between the nurse and the patient and the patient's family have great influence on organ donation process. So far, the influence of the nurses' attitudes towards organ donation and transplantation on the efficiency of the process itself was not sufficiently studied within the national framework.

The influence of numerous factors on the formation of attitudes about organ bequest in our country, such as religion, education level, tradition and customs as well as media propaganda is evident. Archaic customs and animistic beliefs are preserved in the funeral tradition of our people even today. Through customs, we acquire convictions, i.e. beliefs that something is right and true and thus a conviction, which actually represents the judgment or attitude based on belief, is formed. The influence of religion in a nation is of great importance since the religion represents a characteristic of a nation and thus promotes certain principles and norms. Depending on the nationality, the customs and attitudes differ. According to the Population Census in 2011, there are 21 nationalities in Serbia, the most numerous of which are: Serbian 83.32\%, Hungarian 3.53\%, Romani $2.05 \%$, Bosnian 2.02\% and Muslim 0.31 \%. Considering denominations, there are: Orthodox Christian $84.59 \%$, Catholic 4,96\%, Protestant 0.99\%, Islam 3,10\%, Agnosticism 0,05\% and Atheism $1.11 \%$ (8). The participants of the survey were mainly of Orthodox Christian denomination. The concept of the funeral and the rituals for the deceased in Serbia are the embodiment of various social, religious (both Christian and pagan) and historical influences. Religions usually have a positive outlook on transplantation, however, regardless of the positive attitudes of their churches, the believers do not change the ritual concept of the funeral in which the body should be buried in its entirety. The influence of the pagan customs has an effect on the decision of the relatives not to give consent for organ donation, which is only one of the sociological phenomena of the modern Serbian society. Medical professionals, as a professional group, are not incorporated in the modern concept of organ bequest because the influence of the general community reflects the negative attitudes on the issue. The influence of religious factors on the formation of attitudes on organ bequest and transplantation was noted by other studies. In China, one of the leading problems in organ donation is traditional religious ethics (9). The influence of the religious leaders in Islam on the formation of attitudes on transplantation plays an important role and, although Islam as a religion has a positive attitude towards transplantation, the religious leaders need additional education so that they would promote organ bequest themselves (10).

The survey we conducted showed that the participants had some basic knowledge about transplantation and organ bequest, but there is a need to improve it so that it can be implemented in every day practice (Table 1 ). The level of information on the topic was not adequate and thus a small number of the participants were aware of the Law on Transplantation and Organ Bequest which represented a continuation of the trend from 2011 when a similar survey was conducted (11). Nurses in Australia were highly informed about the law which regulated the area of organ donation and bequest (12). The use of mass media in the society bears certain weight in perception of attitudes and their acceptance by an individual and the community. Therefore, it can be said that the mass media have significant influence on the formation of attitudes of not only individuals, but also the overall community. Media campaigns for educational purposes can significantly influence the formation of positive attitudes on organ bequest (13). It is interesting that the nurses who participated in the survey agreed with the general attitude that the influence of mass media was of great importance on the formation of attitudes on organ bequest. In our country, numerous organizations of civil society and some of the Ministries started campaigns using all available media resources. The Ministry of Health, in 2010, started the campaign "Prolong Life" with the aim to inform the public about the importance of transplantation as the only treatment modality in some cases and to increase the number of donors.

Some of the most important elements of the professional action are sympathy, support and informing the donor's family (14). Empathic attitude of the participants in our study towards the families of donors was the result of professional action. The participants also thought that those who bequeath their organs should have certain benefits in terms of health insurance etc. One of the significant preconditions for organ bequest is the conversation with the families about their future desires and personal intentions. According to our survey, the majority of the participants did not talk to their families about organ bequest, unlike the nurses in Spain who talked to their partners and families (15).

Education level represents one of the key factors in the formation of attitudes on transplantation and organ bequest. Educational processes have an influence on the development of the personality and thus it is believed that there is a high correlation between the education and personality development. Formal education is certainly of great significance, but informal education also represents a factor which can influence that the social determinant of a negative attitude in the form of prejudice or not being informed, could be transformed into positive attitude. A survey conducted in Hungary showed that it is desirable to conduct 
informal education in the form of courses, trainings or seminars among medical professionals for the purpose of knowledge improvement and formation of positive attitudes on transplantation (16). Our survey showed that the nurses thought they had a significant role in the provision of information about home care for the patients who had undergone transplantation. However, they were of the opinion that they lacked detailed information on some specific issues and were willing to broaden their knowledge via any kind of educational activities and professional development. A study conducted among the medical professionals in Taiwan showed that the education had a great influence on the formation of attitudes on organ bequest (17). That there was a need for more information about the transplantation on an academic level was shown in a study conducted in the
South-East of the United States of America (18).

\section{Conclusion}

Culture, religion and education are the factors which significantly influence the formation of attitudes on organ bequest and transplantation. The nurses who participated in our survey did not demonstrate an exemplary level of knowledge and readiness to donate organs. It is necessary to conduct more surveys, as well as to promote transplantation and organ bequest in the population of medical professionals.

\section{Gratitude}

The authors thank Ms. Ivana Knezević-Spasović for professional translation of the work from Serbian to English.

\section{References}

1. Supek R. Ispitivanje javnog mnijenja. Zagreb: Naprijed; 1968: 21.

2. Šćepanović D. Debate on the challenges of organ transplantation in our country. Tribune Bioethics Society of Serbia, Beograd. [Internet]. (updated 2016 Nov) Available from:

http://www.domomladine.org/debate/tribinaizazovi-transplantacije-organa-kod-nas-i-u-svetu/.

3. Cantarovich F, Heguilén R, Filho MA, Duro-Garcia V, Fitzgeral R, Mayrhofer-Reinhartshuber $D$, et al. An international opinion poll of well-educated people regarding awareness and feelings about organ donation for transplantation. Transpl Int 2007: 512-8. (CrossRef) (PubMed)

4. Dalkey N, Helmer O.An Experimental Application of the Delphi Method to the use of experts. Management Science 1963: 9(3): 458-67. (CrossRef)

5. Diamond IR, Grant RC, Feldman BM, Pencharz PB, Ling SC, Moore AM, et al. Defining consensus: a systematic review recommends methodologic criteria for reporting of Delphi studies. J Clin Epidemiol 2014; 67: 401-9. (CrossRef)(PubMed)

6. Okoli C, Pawlowski SD. The Delphi method as a research tool: an example, design considerations and applications. Inform Manag 2004; 42(1): 1529. (CrossRef)

7. Zakon o transplantaciji organa. Službeni glasnik RS, $72 / 2009$.

8. Census of Population, Households and Dwellings in the Republic of Serbia. Statistical Office of the Republic of Serbia Statistical Office of the Republic of Serbia (Belgrade); 2012: 15

9. Sui W, Zheng C, Yang M, Dai Y. Organ donation in China: current status, challenges, and future development. Prog Transplant 2014; 24(4): 37580. (CrossRef) (PubMed)

10. Uskun E, Ozturk M. Attitudes of Islamic religious officials toward organ transplant and donation. Clin Transplant 2013; 27(1): E37-41. (CrossRef)(PubMed)

11. Vlaisavljević Z, Milutinović D, Milićić B, JesićVukićević R. Attitudes and knowledge of nurses on organ legacy and transplantation. Srp Arh Celok Lek 2014; 142(3-4): 213-8. (CrossRef)(PubMed)

12. Zettel G, Horvath A, Vorobyeva E, Auburger C, Zink $M$, Stiegler $P$. et al. What ICU nurses in different Austrian hospitals know and think about the Austrian organ donation law. BMC Med Ethics 2014 $; 17 ; 15: 46$. (PubMed)

13. Salim A, Berry C, Ley EJ, Schulman D, Navarro S, Chan LS. Utilizing the media to help increase organ donation in the Hispanic American population. Clin Transplant 2011; 25(6): E622-8. (CrossRef)(PubMed)

14. Murray L, Miller A, Dayoub C, Wakefield C, Homewood J. Communication and consent: discussion and organ donation decisions for self and family. Transplant Proc 2013; 45:10-12. (CrossRef)(PubMed)

15. Zambudío AR, Martínez-Alarcón L, Parrilla $P$, Ramírez $\mathrm{P}$. Attitude of nursing staff toward organ donation in a Spanish hospital with a solid-organ transplant program. Prog Transplant 2009; 19(4): 371-7. (CrossRef) (PubMed)

16. Smudla A, Mihály S, Okrös I, Hegedűs K, Fazakas J.The attitude and knowledge of intensive care physicians and nurses regarding organ donation in Hungary-it needs to be changed. Ann Transplant 2012; 17(3): 93-102. (CrossRef)(PubMed) 
17. Shu-Mei Liu, Hung-Ru Lin, Frank L. Lu, Tzu-Ying Lee. Taiwanese parents' experience of making a "do not resuscitate" decision for their child in pediatric intensive care unit. Asian Nursing Research 2014; 8 (1); 29-35. (CrossRef)( PubMed)
18. Hoy $\mathrm{H}$, Alexander $\mathrm{S}$, Frith KH.Effect of transplant education on nurses' attitudes toward organ donation and plans to work with transplant patients. Prog Transplant 2011; 21(4): 317-21. (CrossRef)(PubMed)

\title{
Originalni rad
}

\section{ISPITIVANJE ZNANJA I STAVOVA GLAVNIH SESTARA O TRANSPLATACIJI ORGANA}

\author{
Željko Vlaisavljević1,2, Slobodan Janković2, Ivan Soldatovićs
}

\author{
${ }^{1}$ Klinički centar Srbije, Klinika za gastroenterologiju, Beograd, Srbija \\ 2Univerzitet u Kragujevcu, Medicinski fakultet, Kragujevac, Srbija \\ ${ }^{3}$ Univerzitet u Beogradu, Medicinski fakultet, Beograd, Srbija \\ Kontakt: Željko Vlaisavljević \\ Ul. dr Koste Todorovića 2, 11000 Beograd \\ E-mail: kcszeljko@gmail.com
}

Transplantacija organa predstavlja jedinu mogućnost za lečenje nekih bolesti. Znanje i stavovi medicinskih sestara i tehničara o transplantaciji organa su od vitalnog značaja za njihovu proaktivnu ulogu u regrutovanju potencijalnih davalaca. Nekoliko faktora može imati pozitivan ili negativan uticaj na njihove stavove, a od njih su najznačajniji religija, nivo obrazovanja i trajanje radnog angažovanja. Cilj ovog istraživanja bio je da pomogne boljem razumevanju nivoa znanja i stavova glavnih sestara i tehničara u pogledu donacije organa i transplantacije i da identifikuje faktore sa pozitivnim i negativnim uticajem. Većina glavnih sestara i tehničara nema dovoljno znanja o srpskom Zakonu o transplantaciji $(77,8 \%)$. Drugi značajan faktor koji je uticao na stavove glavnih sestara i tehničara o donaciji organa bila je religija $(70,4 \%)$, dok je samo $14,8 \%$ glavnih sestara i tehničara bilo saglasno da budu registrovani kao potencijalni davaoci organa.

Acta Medica Medianae 2017;56(4):38-44

Ključne reči: stavovi medicinskih sestara $i$ tehničara, transplantacija $i$ donacija organa, Delfi tehnika, medicinske sestre i tehničari 